\title{
Effects on Environment and Health by Garments Factory Waste in Narayanganj City, Dhaka
}

\author{
Md. Masud Alom \\ Department of Civil \& Environmental Engineering, Uttara University, Dhaka, Bangladesh
}

Email address:

masud_ruet50@yahoo.com

\section{To cite this article:}

Md. Masud Alom. Effects on Environment and Health by Garments Factory Waste in Narayanganj City, Dhaka. American Journal of Civil Engineering. Vol. 4, No. 3, 2016, pp. 80-83. doi: 10.11648/j.ajce.20160403.13

Received: March 22, 2016; Accepted: April 5, 2016; Published: April 27, 2016

\begin{abstract}
Bangladesh has more reputation for Readymade Garments in the world and which plays a significant role in the economical enhancement as well. Most of the garments factories in Bangladesh are located at Gazipur and Narayanganj industrial area, Dhaka. But in terms of pollution, the garments factory has been disgraced as being one of the world's most perpetrators. Now a day's environmental problems are completely anchored in our ways of life. The main goal of this study is to find out the environmental and social problems which arise from garments waste of Narayanganj city and propose some ways of mitigation measures. This is done by analyzing and observing numerous data acquired from field survey. The field surveys were conducted among 100 general people near the study area, some VIP's and some NGO's. Findings from this study are that, the waste management systems are progressing very softly. So the garments factory need to improve the waste management system immediately and NGO side to help to raise the environmental condition.
\end{abstract}

Keywords: Garment Waste, Environmental Effects, Social Problems, Waste Management, Mitigation Measures

\section{Introduction}

Bangladesh is a developing country. Between 2004 and 2014, the averaged GDP growth rate is 6\%. Economic development of this country is depend on firstly on agriculture and secondly on industry. Although Bangladesh is not rich in industry, it has been enriched in Garment industries in the recent past years, which is a promising step. At present Bangladesh is the third largest garment manufacturer and exporter country in the world [8]. Narayanganj is a city in central Bangladesh. It is located in the Narayanganj District, near the capital city of Dhaka and has a population of $29,48,217$ [2]. The city area of Narayanganj is $760 \mathrm{~km}^{2}$. The city is on the bank of the Shitalakshya River. The river port of Narayanganj is one of the oldest in Bangladesh. It is also a center of business and industry, especially the jute trade and processing plants, and the textile sector of the country. As most of the garments industry are situated here and the proper waste management system are not followed by the garments factory, the environmental condition of this area are going to be worst situation day by day. Environment management system and policy impersonation are still far away from being workable. Policies of environment have often been lack ofcongruence among environmental acts, antithetical interests at several levels of the propulsion and resources available to environmental institutions to carry out their responsibilities. Solid waste disposal possesses a greater problem because it leads to land pollution when openly dumped, water pollution when dumped in low land and air pollution when burnt [1].

\section{Objectives}

- Find out the waste generation source of Garments industry in Narayanganj city.

- To investigate the environmental effects and health hazard of the people who are living near the study area.

- Provide some recommendations for solving the existing problems.

\section{Background of the Study}

The numbers of garments are increasing significantly in Narayanganj city due to heavy inrush of immigrants from rural area. In general, environmental scenario of this area is 
too hazardous for garments waste. At present there are about 6500 garment industries in Bangladesh and $75 \%$ of them are in Dhaka. The rest are in Chittagong and Khulna. These Industries have employed 5000000 of people and 85 percent of them are letter less rural women. About 76 percent of our export earning comes from this sector.

According to Jaspal Singh, textile processing are very important and major stages which are from raw material fiber to yarn and then fabric until at the end of ready products [5]. In order to understand the process of textile production it is necessary to get familiar with key process of entire textile making. There are some phases like carding, spinning, warping and weaving these four steps are mostly important [3]. In general, in order to improve entire process of textile wastes, under the technology prospective managing and utilization of whole process is necessary for efficient [6]. Reserve logistics are the terms of activities which are included in the field of waste management. It is the methods of implementing, systematizing the efficiency, making costeffective flow of raw materials, updating and upbringing information within logistics activities, which are connected to each other such as process inventory, finished goods and other information from the point of origin to the point of expenditure and other modes of disposal. Waste management is important for the processing of logistics comes into the category of green logistics; the process which manages all the activities at least cost is termed as green logistics.

In the 1980's the environmental debate gained momentum as methods such as the precautionary principle were being developed and implemented against a rising tide of litigation against organizations possible for environmental degradation [4]. Environmental management practices are often promoted as a cost-cutting opportunity but for many managers this is not a reality. the pressure of implementing green centered around structures such as environmental auditing, impact assessment and accreditation, which has high [10].

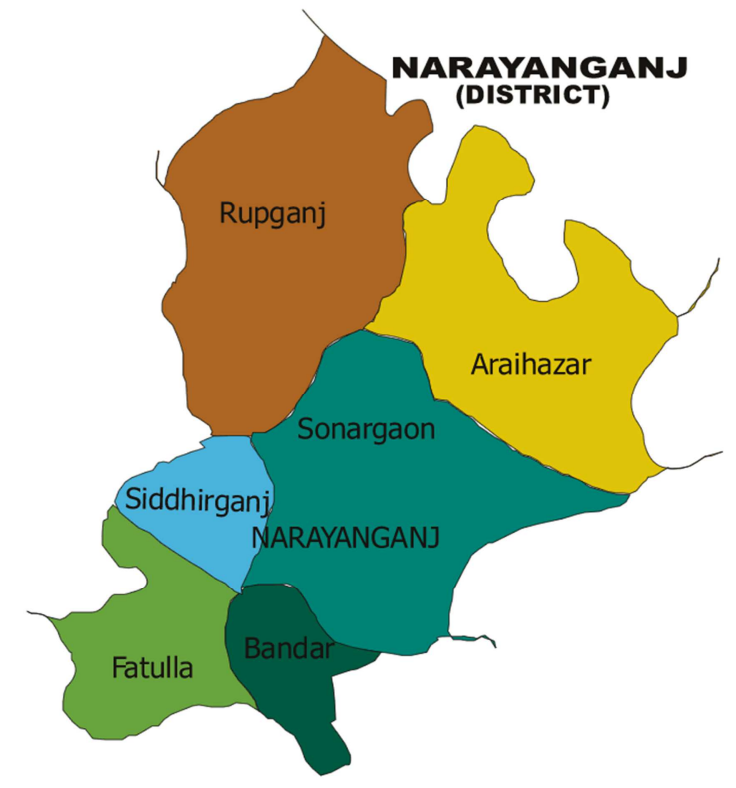

Figure 1. Narayanganj District Map.

\section{Methodology}

A methodology is the systematic, theoretical analysis of the methods applied to a field of study, or the theoretical analysis of the methods and principles associated with a branch of knowledge. Methodology cannot provide solutions but offers the theoretical underpinning which method can be applied to a specific case.

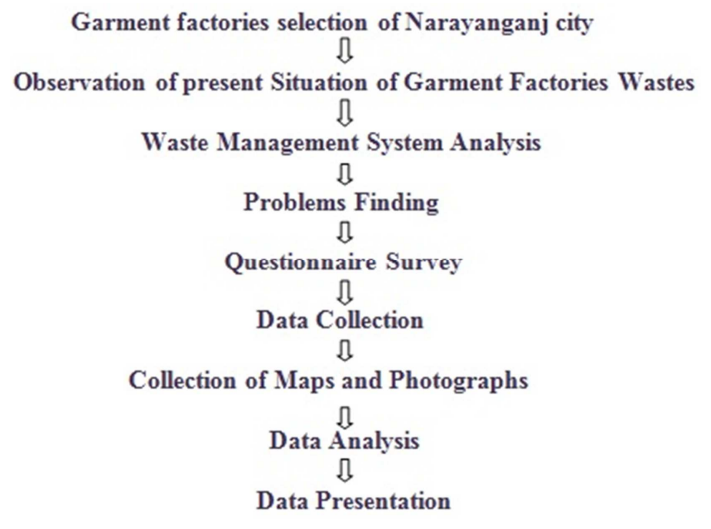

Figure 2. Flow Chart of Methodology.

\subsection{Selection of Garment Factory}

In Narayanganj city significantly the numbers of garments are increasing everyday due to heavy influx of migrants from rural area. At present there are about 6500 garment industries in Bangladesh and 75 percent of them are in Dhaka. The rest are in Chittagong and Khulna. In this study 10 effective Garments factories are selected from Narayanganj city, which are: DNV Clothing, NR Knit Composite, Pioneer Sweaters \& Knit wears Unit-1, Creative Wool wear, Sharoms Samsons Winter Wear, Shore to Shore Textiles, Young 4 Ever, Space Sweater, Aboni Knitwear, Shasha Garments.

\subsection{Present Situation of Garment Factories Wastes}

Predominantly, Narayanganj city is called an industrial city. Most of the textile waste originates during yarn and fabric propagation, processes of garment-making and from the retail industry. According to Jing, waste is one kind of discarded materials which have to discarded, in order to make new raw material for reuse for new products [7]. The extensive amount of industrial waste such as, polyethylene, cloth and papers are generated here daily. Narayanganj Pourashava authority is the only responsible organization for waste management in this area. Everyday 120 to 125 tons waste are generated in this area [9].

Table 1. Type of Garments Waste.

\begin{tabular}{ll}
\hline Types of waste & Total waste (\%) \\
\hline Cutting & $59 \%$ \\
Dyeing & $21 \%$ \\
Knitting & $13 \%$ \\
Sewing & $3 \%$ \\
Others & $4 \%$ \\
\hline
\end{tabular}

(Source: field survey) 


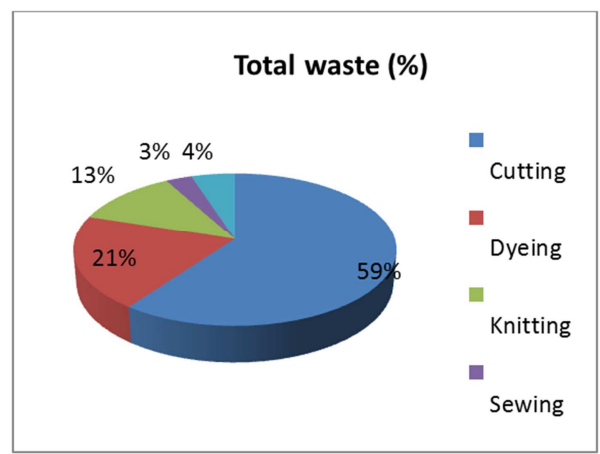

Figure 3. Status of Garments Waste.

\subsection{Waste Management System}

The compositions of various wastes have varied over time and location, with industrial development and which is directly linked to waste materials. Some of the components of waste have beneficial value and can be recycled once correctly recovered. Proper management of waste can be reduced the negative impacts on environment and society. Waste management system can be divided into five key components which are: i) Generation, ii) Storage, iii) Collection, iv) Transportation and v) Disposal of waste. In European textile waste management, there are important activities which are included in the field of waste management. thus the term is called reserve logistics, reverse logistics is the process of implementing, controlling the efficiency, making cost effective flow of raw materials, updating and keeping information within logistics activities which are interlinked to each others such as, process inventory, finished goods and other information from the point of origin to the point of consumption and other process of disposal. It is important the applications of logistics in textile waste management, when the process of logistics comes into the category of green logistics; "green logistic" is the process which manages all the activities at minimum cost of process.

\subsection{Problems Finding}

Various problems are found by this study which is created by the garments waste. Some kinds of problems are environmental and some are human health related. From the observation of questioner survey it is found that, by improper garments waste management, it affects: i) human health ii) Socio-economic conditions iii) Coastal and marine environment iv) Rivers and also v) Affects soil by land filling. The opinions of the people whose are facing different types of problems around the study area, obtained by field survey are listed below.

Table 2. Types of problems around the study area

\begin{tabular}{ll}
\hline Types of Problem & Opinion of total people by (\%) \\
\hline Health Risk & $60 \%$ \\
Insects & $11 \%$ \\
Toxic substances & $19 \%$ \\
Odour & $10 \%$ \\
\hline
\end{tabular}

(Source: field survey)

\subsection{Questionnaire Survey and Informal Interview}

A field survey as questionnaire survey and open discussion has been conducted with the authorities of different concerned organizations, experts and people living near the study area for evaluating the waste management system of garment factories which affect on Environment and health of general people. The questionnaire was designed in such a way that it would track down the problems of environment and general people which help us to sort out some recommendations. About 100 respondents were interviewed in different zones near the garment factories. Informal interview of official experts of different development organizations and some VIP's were also done in order to know their views of the waste management system which affects on environment of Narayanganj city.

\subsection{Data Collection and Other Secondary Data}

To fulfill the objectives of this study both primary and secondary data were needed. All the necessary data has been collected from various sources. We have collected these data's through 3 different processes, i) Questionnaire survey with general people, ii) Informal interview with different organization and iii) Informal interview with different garment's VIP persons. The data's are collected from the organization's who works for the welfare of Environment and from the VIP persons who are experts of their fields and can give a valuable opinion about this environmental study.

\subsection{Collection of Photographs}
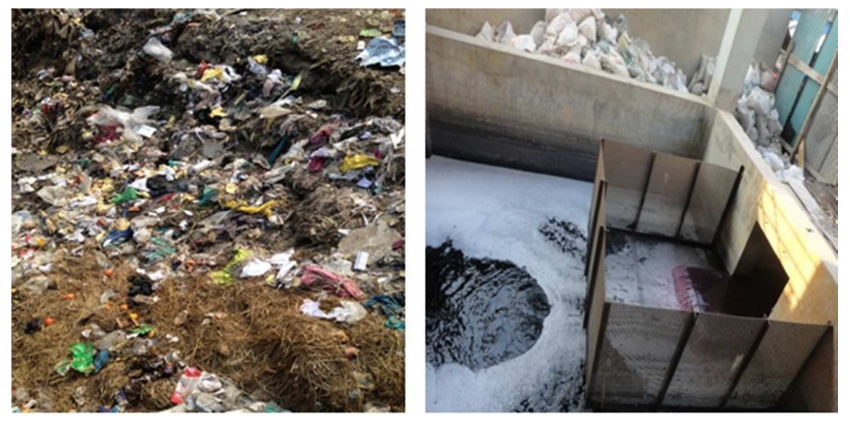

Figure 4. Garments factory waste generation.

Lots of photographs were collected to illustrate the waste management system of the garment factories in Narayanganj city. Some of the photographs have been collected directly from the field survey and some others from daily newspapers as well as from internet website.

\subsection{Data Analysis and Presentation}

All the collected data from field survey were putted in a spread sheet and analyzed separately according to the respondent opinion and finally all the analyzed data (\%) have been integrated and presented as tables and graphs and putted in the report. 


\section{Recommendations}

As a conscious citizen of any country, everyone have some common dreams like neat, clean and poverty free society. Government cannot bear this responsibility alone. For fulfilling these dreams, we have to take some initiatives together and share these obligations each other. For keeping the locality clean, City Corporations already start to organize their own waste collection services. Following steps can help the authorities for extensive management of Garments waste and reduce the enduring of the city dwellers from physical, social and environmental point of view

- Government and owner of garments factories should conscious about environmental Act and try to follow the rules and regulations strictly.

- Effluent treatment plant (ETP) installation can be mandatory for all garments industry for decreasing the toxicity of the produce waste.

- Where the amount of waste is more, the number of bins should be increased and placed at proper place of garments side.

- For quick transport of waste the vehicles such as Container carrier, Compactor, Arm roller, Van etc. should be on proper operation and if necessary, more vehicles need to be included.

- Can be organized effective training programe about health \& hygiene as well as overall environment among the employees of the factory.

- Properly follow the systematic procedure of waste disposal and ensure while handling the wastes, workers must use their safety equipment like mask, hand gloves, boot etc.

- The NGOs- Government partnership should be exhibited and promote the citizen monitoring mechanism to proper evaluation, efficiency and effectiveness of national as well as foreign aid program in the sector of environment.

- The industries like Textile and others harmful factories can be transferred outside the City and proper drainage system should be ensured by the government.

\section{Conclusion}

In industrial areas, the local environment and peoples are influenced by both chemical and organic pollutants, because of textile dyeing industries. From this study it is found that, large quantities of effluent are discharging by the textile dyeing industries in Narayanganj City. These can be highly toxic and composed of various physicochemical pollutants at significant upper level than standard value of department of environment. Some of the industries have authentic effluent treatment plant (ETP) for treating waste water. As most of the factories specially dyeing industries are throwing their waste directly to Shitalakkhya River without treatment, the water of this river is getting highly polluted. Most of the people living near this area are facing different health related problems. The increasing number of textile dyeing industries in this area, the concentration of these pollutants is increasing in an alarming rate. So it is necessary to take initiatives immediately to minimize the pollution to a significant extent and reduce health hazard problems. That is the way to increase environmental benefits for future generation.

\section{References}

[1] Akter NR, Acott E, Sattar MG, Chowdhury SA (1997). Environmental Investigation of Medical W aste Disposal at BRAC Health Centre's. BRAC, Research and Evaluation Division, 75 Mohakhali, Dhaka 1212, Bangladesh. pp. 16-18.

[2] BBS (2011). Bangladesh Bureau of Statistics Bangladesh. Community Report: Nayarayanganj, Dhaka, Bangladesh.

[3] Bhushan $(2009,165)$. The process and production of textile. Viewed 02.02.2015

[4] Glasson, J. Therivel, R. and Chadwick, A.(1999) Introduction to Environmental Impact Assessment: Principles and procedures, process, practice and prospects, 2nd edition, UCL Press, London

[5] Jaspal Singh (2009) Textile processing. Viewed 02.02.2015.

[6] Jing, Z. $(2012,7)$ an analysis of textile waste management. HAMK University of applied sciences. Supply Chain Management Degree program. Bachelor's Thesis.

[7] Jing, Z. (2012, 9) an analysis of textile waste management. HAMK University of applied sciences. Supply Chain Management Degree program. Bachelor's Thesis.

[8] Kakuli A. and Risberg V., 2012. A lost Revolution? Enpowered but trapped in poverty. Women in the garment industry in Bangladesh want more, Swedwatch report \#47.

[9] Narayanganj Pourashava. (2009). Rough estimate of Solid Waste Collection Database.

[10] Tzschentke, N., Kirk, D. \& Lynch, A. (2008) "Going green: Decisional factors in small hospitality operators" International Journal of Hospitality Management, Volume 27, p. 126-133. 